\title{
How to Get Better Aging, Bet on Positive Psychology
}

\author{
Irani Iracema de Lima Argimon'1, Cristiane Silva Esteves2 ${ }^{2}$, Fernanda Cerutti2, \\ Juan José Mouriño Mosquera ${ }^{3}$, Claus Dieter Stobäus ${ }^{4}$ \\ ${ }^{1}$ Postgraduate Program in Psychology and in Biomedical Gerontology, Pontifical Chatolic University of Rio \\ Grande do Sul, Porto Alegre, Brazil \\ ${ }^{2}$ Postgraduate Program in Psychology, Pontifical Chatolic University of Rio Grande do Sul, Porto Alegre, Brazil \\ ${ }^{3}$ Postgraduate Program in Education, Pro-Rectory of Postgraduate and Research, Pontifical Chatolic University \\ of Rio Grande do Sul, Porto Alegre, Brazil \\ ${ }^{4}$ Postgraduate Programs in Education and in Biomedical Gerontology, Pontifical Chatolic University of Rio \\ Grande do Sul, Porto Alegre, Brazil \\ Email: Stobaus@pucrs.br
}

Received 9 September 2015; accepted 10 November 2015; published 13 November 2015

Copyright (C) 2015 by authors and Scientific Research Publishing Inc.

This work is licensed under the Creative Commons Attribution International License (CC BY).

http://creativecommons.org/licenses/by/4.0/

c) (7) Open Access

\begin{abstract}
The article reviews some contact points between the traditional Psychology, the Positive Psychology and the Health Psychology, with the intention of making reflections in direction of the healthy and better aging, with the support of theoretical ideas and some practical possible implementations for late adults, or persons in the late adulthood stage, chronologically more than 60 - 65, specially in dimensions as better treat, educate and care.
\end{abstract}

\section{Keywords}

Positive Psychology, Aging, Elderly, Psychology

\section{Introduction}

In everyday life we encounter many benefits that are granted to the elderly, such as parking spaces near the entrance locations, preferred passwords in banks, half price for shows and movies, free public transport. All these benefits aim to bring more facilities, but account for only practical issues of quality of life and leave open their emotional and affective demands, that are already part for some time of the development of the life cycle of these elderly, or more modern denomination, of the late adults, seniors or persons in the late adulthood, who already make up much of our population, which tends to increase substantially in the coming two decades, when it 
is expected that some people will live to be 120 years.

It is a global phenomenon of the increasing number of elderly and the improvement in their life expectancy, and thinking about these years, more and better experienced, we began our reflections. Therefore we could say that the phase called late adulthood, up from 60 - 65 years of chronological age, is worrying about both the more developed and so-called advanced societies, such as those under development.

In this study we want to present possibilities for better growth and development, based on the Humanistic Psychology to reach the Positive Psychology and Health Psychology.

As we state and have well in mind, since the second half of the twentieth century to the present time, in the concepts of Adult Life, especially the so-called aging, we find many changes with regard to the new way of seeing the person who forwards to the last phase of his life. Dramatic innovations in the health field, both physical and psychic, have opened possibilities for better moments in human life toward understanding the daily lives and the field of work and new opportunities opening up for people over 60, 65, or 70 years of chronological age.

It is important that, at this time, the attention of not only the timing is critical, but is also functional age, since it broadens the outlook than previously understood by human development, to what we now understand as "revolutions" in culture and society with repercussions on lifestyles of those who called him/her long ago as old or elders, and they now understand with current ways of life and better perspective as a senior, a late adult, both in its health aspects but also on their lifestyle and quality of life.

Then we care to open dimensions to better treat, educate and care for these people who increasingly require our attention as citizens and human beings.

\section{From More Traditional Psychology to Positive Psychology and Health Psychology}

We agree with Veras (2009) when he states that life extension could be considered really as achievement when (better) quality of life is added to these later years chronologically.

By the time we have more lifetime and also more "free" time, we should know and be able to use it well, with quality and intimate satisfaction, while being educators of new generations. With that comes along with concern that there is no point having more free time and live longer if they are not created and optimized the right conditions to live more fully, says D'Alencar (2002).

Or we can say: "more life (quality) in the years and not only over the years to life". We are watching and being part of this movement that is able to add more life to years lived and not just years to life. This is an important reflection we need to do because what is good live many years chronological, if they are not lived with due quality and completeness.

It is then ask how this can live with quality and completeness? Maybe that's a question that leads to different answers. Although scientifically possess a definition for "quality of life", we know that each of us will have their own answer to that question, and it probably will be based on our own experiences, the feeling we have about its relevance in a particular context of life.

According to Carvalho, \& Pinho (2006: p. 202), "the elderly will have to learn to accept and take the inevitable losses in order to feel satisfied and participatory in your life. This adaptation should contextualize itself in its social, economic and cultural reality".

Neri \& Resende (2009) point out that there are numerous ideas and preconceived stereotypes about aging, this stage of life relating more to negative beliefs about functional decline. Despite the conception of old age already be changing gradually over yet being often related only to loss, death and mourning.

Scholars of Positive Psychology, since the late 90s, argue that are the strengths and virtues that can also act as preventive agents and future mental illness protectors. They claim that only alleviate pain or suffering is no guarantee or prevention of possible future situations.

So while the traditional line of Psychology aims more to reduce human suffering, this new line seeks to help produce more happiness/well-being to people's lives and is considered the new science of happiness.

But what exactly it is that Positive Psychology? It is a branch of Psychology that has focused on the attempt to understand the forces of the patient, while Psychology we call (more) traditional proposed to focus more on their weaknesses.

So Positive Psychology is a scientific field within Psychology that takes into account mainly positive expe- 
riences.

Initially well highlighted by Seligman (2004), it is supported on three pillars, namely: 1) study of positive emotions (checking satisfaction with the past, happiness in the present moment and the hope for the future); 2) study of the qualities/positive traits (especially strengths and virtues such as: flexibility, self-control, courage and wisdom) and; 3) study of positive institutions (e.g. school, family, community).

Before continuing to read, answer: what you see in the figure below?

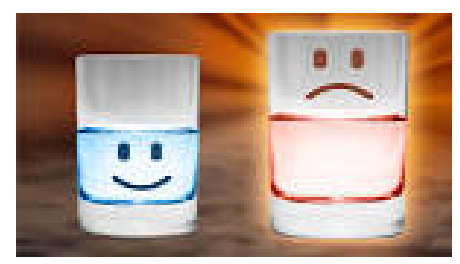

porquegenteeassim.com.br

You saw one half-empty glass? Or a glass half full? The figure exemplifies exactly the theory that we are trying to explain. The most optimistic person will respond that the glass is half full, while the most pessimistic say that is half empty. That's one way to think that the same situation can be seen from different perspectives and can be interpreted as antagonistic to, and not as complementary.

Thus, we understand that the same fact can be seen by a person in a positive or negative way, or two people so even opposite. It is as if the interventions in Positive Psychology we stopped to think about the prism glass half full, even if there is, first, a tendency to see the glass half empty.

This new approach will even "against” the Manual of Statistics and Diagnosis of Mental Disorders (DSM-V, 2014), bringing up the fact that it is made possible only treatments aimed at problems, disorders and deficiencies of the patient. So just focusing mainly points and more negative behaviors, even the professionals have knowledge about healthy attitudes of these people. Remember that the Manual is to encode "disease", and not aspects of health.

Both aspects of disease as a health occur throughout life, is closely connected to a required Continuing Education and Health, as say Faustini, Stobäus, \& Mosquera (2014).

Already Positive Psychology studies the effects of good feelings in people's lives, seeking the meaning to what is healthier for the patient, looking to enhance and extend aspects of their quality of life and even helping to prevent future pathologies.

According to scholars of Positive Psychology, like Seligman (2012), knowing the personal weaknesses is its relevance, but is not enough to promote prevention. We are not criticizing the traditional way of do Psychology, and recognize its effectiveness and importance, there is only a new/different way of thinking about the work within the area, here remembering the extension to the prospect of healthy human aging on the size of Late Adulthood, said Mosquera (1987) and also highlighted by Stobäus, \& Mosquera (2014).

And as work within this line psychologists and educators can help patients/persons? They are seeking help them discover within themselves those qualities that have been developed throughout their lives, helping to identify its most positive aspects, encouraging them to positively take care of themselves. Seek to highlight the patient's character strengths (such as creativity and hope), as well as their individual talents. Thus promoting greater flexibility of thought so that they can analyze their prospects in challenging situations previously unknown, increasing tolerance to frustration and imperfection, providing a sense of self-acceptance. Some of these ideas are also emphasized by Hutz (2014).

Turn out D’Araújo, Alpuim, Rivero, \& Marujo (2015) that intervention strategies in clinical Positive Psychology include: 1) gradual promotion of hope; 2) developing and improving interpersonal skills; c) Construction of protective forces. Thus, part of the search for pleasure (hedonism), the personal growth and a way of life in a healthier future prospective.

As Yanfen, Keli, Jianhua, Jun, \& Jianying (2012), lately the scientific literature related to Positive Psychology has grown significantly in several countries.

However, in Brazil, this growth has not been as significant as Pureza, Kuhn, Castro, \& Lisboa (2012). Given this reality, we realized that the elderly have not been investigated so, in our Brazilian context, possibly not in other countries. This situation tends to change with the Health Psychology in various conferences and meetings 
in the last ten years, as well as research in Master and Doctor Degree Courses in Geriatrics and Gerontology, one of these is at our University-PUCRS.

The work of Lowry, Vallejo, \& Studenski (2012) discusses the positive aspects of this stage of adulthood, and used the following expressions: "healthy aging”, "successful aging”, "active aging”, "optimal aging” and "lately positive aging”.

According to Vaillant (2003) there are seven indicators that predict greater well-being in people with advanced age: 1) friendships and pleasant companies that are grown throughout life; 2 ) be engaged with someone in a genuine way; 3) have a good marriage; 4 ) if you make use of alcohol or tobacco, that this is done in a controlled manner abstinence or controlled use of alcohol and tobacco; 5) the healthy occupation time; 6) the cultivation of social relations; 7) subjective well-being. As to the subjective well-being, we remember the fact that you feel good just having a more positive impact on older than simply owning/maintaining your health.

In studies aimed at investigating the benefits that positive emotions bring to health, with regard to the prevention of chronic diseases, we have access to Ostir, Markides, Peek, \& Goodwin (2001) and Steptoe, Wardle, \& Marmot (2005) works, which stand to think more positive about their experiences reflected in higher quality of life.

Interventions of Positive Psychology facing late adult aim that someone person cultivate his own existence more positively, increasing well-being and life satisfaction.

A better proposal of Positive Psychology intervention model with elderly have to help rethink the concept of life and revise beliefs about aging, learn how to turn the attention to positive aspects and learn from the experiences, encourage self-knowledge of personal qualities, the roles played and life missions, enhance self-care, exploring the acts to thank and forgive.

Finally must be able to create and achieve a goal, as they say Estrela-Dias \& Pais-Ribeiro (2012), working since the late 90's within the Health Psychology field, these aspects that seem to be "abandoned" at this final stage of their life, by the person and also with whom he/she lives.

Still commonly heard in the speech of some people that "the elderly are again children" and therefore do not follow more developing on a personal level. In fact we might ask if it is not the family itself and our society (Latin American, or said, a developing country) in which we live that would be 'infantilize' this late adult person?

Another idea of common sense is to say that in this phase of life "there are no more plans for the future". But they exist, of course are not the same as when the person was 25 or 40 years of chronological age. Thus, interventions based on Positive and Health Psychology proposes to help the person to (re)define these points when think about specific aspects of his/her life.

Our purpose here is not to give ready-made solutions, as a manual or a lecture about Positive Psychology, but bring the main idea of this line so that the person can reflect on aging in a more positive way.

According to Rabelo \& Neri (2006), with old you will not lose the ability to maintain a positive critical sense in relation to yourself and trying to adjust to new realities in a positive adaptive way.

According to D'Alencar (2002: p. 71):

If it is true that losses exist and the elderly decreases agility (time and speed to perform some activity), it is not correct to think that this reflects the elimination of their abilities, the reduction of the skills, nor the curiosity that surrounds or, still, his ability to think.

To be able to positively live this stage of life, it is important that the person seek an understanding of what his/her age can not be only in the linear perspective, linked to chronological age, but is composed of other elements that make up the idea of "functional age" (Stobäus, \& Mosquera, 2014), structured in more critical and mature way, taking into account the physical, mental, emotional, spiritual and social "ages".

Building this understanding is part of our while our work as "educators and caregivers to people", helping the late adults to make sense of this important phase of their life. Part of this process achieve encourage reflection on what were the expectations for when that persons had managed to reach the age that currently have, helping to (re)create and make plans for their life consistent with their 'functional age' and in a socio-cultural context, with a environment in which he/she operates and acts.

We believe it is valid to emphasize again that age positively does not mean "being happy all the time", but would, as it is throughout human life, have moments of happiness, as highlighted by Agnes Heller (1987).

D’Alencar (2002: p. 71) contributes to bringing our caveat that: 
This is not the way to teach the elderly to rejuvenate, either to compete. It is make him/her understand that old age can be another stage of life to be lived positively; for personal growth, a growth that can and should be accompanied by new experiences, interaction and integration in the context they live; to develop new perspectives on life, their surroundings, with a more experienced look, in some serene and even more sympathetic moments, mainly due to the knowledge that has already developed, about yourself, about the reality on the other.

It is important that the environment, the context in which the person develops, may be similarly moved by this positive way of seeing the late adulthood. This phase of life is almost "feared" by most people, and therefore negative beliefs also "contaminate and permeate" often the thinking of those who are rightly responsible for the care of the elderly. It is then up to educators and caregivers (re)view their concepts and ways of acting.

As put Silva, Farias, Oliveira, \& Rabelo (2012), positive emotions strengthen the mental and physical health, substantially dimensions so while possibly taking greater longevity.

Group work with the elderly, aiming to work with more positive aspects, as should substantially dimensions so while possibly providing the strengthening of opportunity those aspects they find most positive and healthy, helping them to promote strengths and virtues. So should the participation of their families and the various social institutions (hospitals, NGOs, schools, universities, ...), which can act together, providing opportunities to become more participatory and hopeful in their society.

\section{Final Comments}

When dealing with this article, on the subject of human aging, and Positive Psychology and Health as a backdrop and as theories that underlie the thinking and acting, we emphasize the need to meet and discuss this new reality that affects us all, and we all go through this stage and we have to (re)view these immediate challenges: what good is a lifetime if we can not give the proper meaning and value?

\section{References}

Carvalho, P. S., \& Pinho, A. P. (2006). Legislação e programas de apoio para o idoso. In: H. Firmino (Ed.), Psicogeriatria (pp. 201-213). Coimbra: Almedina.

D’alencar, R. S. (2002). Ensinar a viver, ensinar a envelhecer: Desafios para a educação de idosos. Estudos interdisciplinares do envelhecimento, Porto Alegre-RS, 4, 61-83.

http://www.google.com.br/url?url=http://seer.ufrgs.br/RevEnvelhecer/article/download/4719/2645\&rct=j\&frm=1\&q=\&esr c=s\&sa=U\&ei=qDluVZuqG5W sQTn6YDoBA\&ved=0CBkQFjAB\&usg=AFQjCNFvGCLggDYLsVupeQ7pyp07uqSrng

D’Araújo, M. A., Alpuim, M., Rivero, C., \& Marujo, H. A. (2015). Possibilidades para envelhecer Positivamente: Um estudo de caso com base na Psicologia Positiva. Revista E-Psi, 5, 40-75.

http://apeipp.com/pages/eventos/d-Araujo-et-al-2015_Possibilidades-para-Envelhecer-Positivamente.pdf

DSM-V (2014). Manual Diagnóstico e Estatístico de Transtornos Mentais (5th ed.). Porto Alegre: Artmed.

Estrela-Dias, M., \& Pais-Ribeiro, J. (2012). Psicólogo nos cuidados continuados integrados: Intervenção Positiva. In 9 Congresso Nacional de Psicologia da Saúde (pp. 418-424). Porto-PT: Actas... Faculdade de Psicologia e Ciências da Educação da Universidade do Porto. http://sigarra.up.pt/fpceup/pt/publs_pesquisa.FormView?P_ID=87512

Faustini, É., Stobäus, C. D., \& Mosquera, J. J. M. (2014). Education and Health: Epidemiological Indicators Can Improve the Continuing Education Process. Creative Education, 5, 1873-1881.

http://www.scirp.org/Journal/PaperInformation.aspx?paperID=51837

http://dx.doi.org/10.4236/ce.2014.521209

Heller, A. (1987). Teoría de los sentimientos. Barcelona: Fontamara.

Hutz, C. S. (2014). Avaliação em psicologia positiva. São Paulo, SP: Casa do Psicólogo.

Lowry, K. A., Vallejo, A. N., \& Studenski, S. A. (2012). Successful Aging as a Continuum of Functional Independence: Lessons from Physical Disability Models of Aging. Aging and Disease, 3, 5-15.

http://www.ncbi.nlm.nih.gov/pmc/articles/PMC3320804/

Mosquera, J. J. M., Vida Adulta. (1987). Desenvolvimento e Personalidade (2nd ed.). Porto Alegre: Sulina.

Neri, A. L. (2011). Teorias psicológicas do envelhecimento: percurso histórico e teorias atuais. In E. V. Freitas et al. (Eds.), Tratado de Geriatria e Gerontologia (3rd ed., pp. 58-77). Rio de Janeiro, RJ: Guanabara Koogan.

Neri, A. L., \& Resende, M. C. (2009). Ajustamento psicológico e Perspectiva de velhice pessoal em adultos com deficiência física. Psicologia em Estudo, 14, 767-776. http://www.scielo.br/pdf/pe/v14n4/v14n4a17 
http://dx.doi.org/10.1590/S1413-73722009000400017

Ostir, G. V., Markides, K. S., Peek, M. K., \& Goodwin, J. S. (2000). Emotional Well-Being Predicts Subsequent Functional Independence and Survival. Journal of American Geriatric Society, 48, 473-478. http://www.ncbi.nlm.nih.gov/pubmed/10811538 http://dx.doi.org/10.1111/j.1532-5415.2000.tb04991.x

Pureza, J. R., Kuhn, C. H. C., Castro, E. K. de, \& Lisboa, C. S. de M. (2012). Psicologia Positiva no Brasil: uma revisão sistemática da literatura. Revista Brasileira de Terapias Cognitivas, 8, 109-117. http://www.rbtc.org.br/detalhe_artigo.asp?id=168

Rabelo, D. F., \& Neri, A. L. (2006). Bem-estar subjetivo e senso de ajustamento psicológico em idosos que sofreram acidente vascular cerebral: Uma revisão. Estudos de Psicologia (Natal), 11, 169-177. http://www.scielo.br/scielo.php?script=sci_arttext\&pid=S1413-294X2006000200006 http://dx.doi.org/10.1590/S1413-294X2006000200006

Seligman, M. E. (2004). Felicidade autêntica: Usando a nova psicologia positiva para a realização permanente. Rio de Janeiro, RJ: Objetiva. [Original: Authentic Happiness: Using the New Positive Psychology to Realize Your Potential for Lasting Fulfillment. New York: The Free Press, 2002.]

Seligman, M. E. (2012). Florescer: Uma nova compreensão sobre a natureza da felicidade e do bem-estar. Rio de Janeiro: Objetiva. [Original: Flourish: A Visionary New Understanding of Happiness and Well-Being. New York: Atria Books, 2012.]

Silva, L. C. C., Farias, L. M. B., Oliveira, T. S. de, \& Rabelo, D. F. (2012). Atitude de idosos em relação à velhice e bem-estar psicológico. Revista Kairós Gerontologia, São Paulo-SP, 15, 119- 140. http://revistas.pucsp.br/index.php/kairos/article/viewFile/13798/10187

Steptoe, A., Wardle, J., \& Marmot, M. (2005). Positive Affect and Health-Related Neuroendocrine, Cardiovascular and Inflammatory Processes. Proceedings of the National Academy Science of United States of America, 102, 6508-6512. http://dx.doi.org/10.1073/pnas.0409174102

Stobäus, C. D., \& Mosquera, J. J. M. (2014). Positive Psychology and Emotional Schedule: Building Healthy SelfConstruction. Psychology, 5, 533- 540. http://www.scirp.org/journal/PaperInformation.aspx?PaperID=45269 http://dx.doi.org/10.4236/psych.2014.56063

Vaillant, G. E. (2003). Aging Well. New York: Little Brown.

Veras, R. (2009). Envelhecimento Populacional Contemporâneo: Demandas, Desafios e Inovações. Revista Saúde Pública, 43, 548-554. http://www.revistas.usp.br/rsp/article/view/32632 http://dx.doi.org/10.1590/S0034-89102009000300020

Yanfen, F., Keli, Y., Jianhua, W., Jun, T., \& Jianying, L. (2012). Bibliometric Analysis of Positive Psychology in China. Journal of Dali University, 11, 93-96. http://118.145.16.228:8080/jwk dlxysk/EN/abstract/abstract8517.shtml 